\title{
RECENZJE
}

Klio. Czasopismo poświęcone dziejom Polski i powszechnym PL ISSN 1643-8191, t. 27 (4)/2013, s. 245-289

\section{Archiwa dla nauki. Dlaczego nauce potrzebne sq archiwa naukowe?, red. Tomasz Filip, Kraków 2011, ss. 127}

\section{(c) $(1) \Theta$}

DOI: http://dx.doi.org/10.12775/KLIO.2013.057

W

ostatnich latach można zaobserwować rosnące zainteresowanie archiwami naukowymi, czyli takimi, które gromadzą dokumentację ukierunkowaną na: po pierwsze - konkretne dziedziny naukowe, po drugie - badaczy zajmujących się nimi oraz spuścizny pozostawione przez naukowców. Niewiele jest publikacji dotyczących tego zagadnienia, zwykle są to pojedyncze głosy w artykułach bądź wystąpieniach na konferencjach naukowych.

W listopadzie 2007 roku odbyła się konferencja zorganizowana przez Archiwum Nauki Polskiej Akademii Nauk (PAN) i Polskiej Akademii Umiejętności (PAU), Komisje Historii Nauki PAN oraz Krakowski Oddział Stowarzyszenia Archiwistów Polskich pt. Archiwa dla nauki. Dlaczego nauce potrzebne archiwa naukowe? Cztery lata później ukazały się drukiem materiały z tej konferencji, które stanowią jedną z niewielu publikacji w całości poświęconych problematyce archiwów naukowych. Ukazały się one pod redakcją Tomasza Filipa i są zbiorem studiów przygotowanych w głównej mierze przez badaczy, którzy zajmują się opracowaniem i gromadzeniem tej dokumentacji w archiwach, a także tych, którzy są użytkownikami archiwów i często z nich korzystają.

Omawiana praca nie jest obszerna, liczy 127 stron. Publikację otwiera wstęp Jerzego Wyrozumskiego, sekretarza generalnego PAU. Następnie przedstawiono osiem artykułów, dwa komunikaty oraz wybrane głosy w dyskusji. 
Pierwszy artykuł Andrzeja Pelczara z Uniwersytetu Jagiellońskiego pt. „Archiwum w nauce. Nauka w archiwum” w swojej wymowie oscyluje przede wszystkim wokół badań nad historią matematyki. Autor wymienia materiały dotyczące historii matematyki, których poszukują badacze zainteresowani m.in. materiałami biograficznymi, rozwojem idei naukowych, śledzeniem indywidualnych dróg naukowych poszczególnych badaczy. A. Pelczar podaje przykłady notatek czynionych na marginesach głównych prac przez Jana Brożka i Tadeusza Ważewskiego, które są istotne dla osób mających zamiar śledzić przepływ informacji naukowych oraz ich rozwój. Zwraca uwagę na to, aby w archiwach naukowych bardziej skrupulatnie niż do tej pory katalogowano zbiory oraz sugeruje, by współcześnie gromadzić w archiwach naukowych brudnopisy elektroniczne, które są doskonałym przykładem rozwoju nauki. Na ten problem coraz częściej zwraca się uwagę w chwili obecnej, uznając tzw. raw data, czyli brudnopisy naukowe, za bardzo istotny wkład w dokumentację obrazującą historię nauki.

Zbigniew Mirek z Instytutu Botaniki PAN w artykule „Archiwa w naukach przyrodniczych" zaproponował podział materiałów archiwalnych nauk przyrodniczych. Zwrócił uwagę na to, że zbiory przyrodnicze stanowią „swoiste archiwalne okazy” bogate w przykłady i okazałą ikonografię, podając za przykład zielniki botaniczne. Na koniec spostrzegł, że w przyrodniczych placówkach naukowych nie ma tradycji gromadzenia archiwaliów, czego należy szczególnie żałować.

„Archiwa w naukach medycznych” to artykuł Zdzisława Gajdy z Collegium Medicum Uniwersytetu Jagiellońskiego. Autor zauważa przede wszystkim to, że w medycynie nie przywiązuje się większej wagi do archiwów, wyjaśniając dalej, co rozumie się pod pojęciem „archiwalia w medycynie”. Z. Gajda podaje przykład Zakładu Historii Medycyny CM UJ, który posiada zbiór historii chorób z kliniki profesora Brodowicza z lat 1823-1850, spisanych w 4500 zeszytów, co stanowi ewenement na skalę światową, tym samym potwierdzając tezę, że zasób materiałów archiwalnych z dziedziny medycyny jest bardzo skromny. Na koniec wystosowuje prośbę o zachowywanie całej spuścizny, skierowaną przede wszystkim do rodzin po zmarłych lekarzach, które niejednokrotnie pieczołowicie zachowują biblioteki po zmarłym, natomiast często wyrzucają materia- 
ły rękopiśmienne, mające najwyższą wartość dla badań z zakresu historii medycyny.

Adam Cieślak z Archiwum Uniwersytetu Jagiellońskiego w artykule „Archiwa naukowe w Europie i na świecie” przedstawił historię rosnącego zainteresowania wyprofilowanymi archiwami naukowymi, której początek miał miejsce w 1997 roku w Paryżu na pierwszym spotkaniu zrzeszającym archiwistów instytucji naukowych. Zwrócił też szczególną uwagę na potrzebę gromadzenia materiałów naukowych przez archiwistów, stawiając jednocześnie pytanie o kryteria zachowania materiałów naukowych. Jest to kwestia bardzo istotna dla archiwistyki, ponieważ do tej pory nie ukazały się żadne wytyczne, według których archiwa naukowe powinny kształtować zasób.

Marek Ďurčanský z Uniwersytetu Karola w Pradze w artykule „Archiwa specjalistyczne i ich rola w gromadzeniu źródeł do historii nauki w Republice Czeskiej” poruszył bardzo ciekawy temat. Mianowicie omówił dwa zasadnicze typy zespołów archiwalnych w archiwach naukowych: 1) zespoły, które mają pochodzenie instytucjonalne i powinny trafić do archiwum drogą naukową; 2) materiały pochodzenia prywatnego. Oba typy materiałów, jak zauważa Ďurčanský, doskonale się uzupełniają. Różnica między nimi jest w pierwszym wrażeniu jasna i klarowna, również na gruncie polskim, choć autor odnosi się do rzeczywistości i prawa Republiki Czeskiej, gdzie obowiązują stosowne przepisy prawne. Mając na uwadze sytuację w Polsce, pojawia się następujący problem: kiedy naukowiec jest pracownikiem instytucji naukowej, na rzecz której prowadzi badania, publikując wyniki pod egidą owej instytucji, czy wówczas cała jego dokumentacja jest własnością prywatną, czy też powinna znaleźć się ona w aktach instytucji? Okazuje się, że badacze niechętnie przekazują do archiwów naukowych swoje brudnopisy i zapiski, które swoją wartością informacyjną przewyższają inne materiały zarchiwizowane w zbiorach instytucji naukowych, traktując je jako prywatną własność. Szczególnym przykładem archiwizowanych materiałów jest dokumentacja dotycząca realizacji grantów, która jest gromadzona w instytucjach naukowych, mimo że nie przedstawia wielkiej wartości dla historii nauki czy rozwoju idei naukowych, zwłaszcza gdy są to przede wszystkim rozliczenia grantowe i sprawozdania - nierzadko bardzo lako- 
niczne - oraz publikowane wyniki badań, stanowiące efekt końcowy wykonania grantu.

„Kształtowanie się modelu sprofilowanego archiwum gromadzącego źródła do historii nauki” przedstawiła Rita Majkowska z Archiwum Nauki PAN i PAU. Na przykładzie Archiwum UJ i Archiwum Nauki autorka artykułu przedstawiła przede wszystkim procesy pozwalające określić i wytypować pewne cechy charakterystyczne dla sprofilowanego archiwum naukowego, które mogłyby stać się przykładem modelowym dla działających i tworzonych archiwów tego typu. R. Majkowska stwierdziła, że archiwa takie powinien cechować wyspecjalizowany profil gromadzenia, w którym obok zespołów kancelaryjnych instytucji naukowych, stowarzyszeń, wydawnictw powinny znajdować się również spuścizny badaczy. Powinno się również gromadzić dokumentację audiowizualną, tworzyć specjalistyczną metodykę opracowania zasobu, pomoce archiwalne, publikować prace fachowe i źródła do historii nauki oraz opracowywać określone kryteria działań na przedpolu archiwalnym, co należy rozumieć jako ścisłą współpracę ze specjalistami w zakresie określania wartości dokumentów wytwarzanych przez instytucje naukowo-badawcze i ludzi nauki.

Diana Błońska z Archiwum Uniwersytetu Jagiellońskiego w swoim artykule „Źródła do dziejów nauki w zbiorach Archiwum Uniwersytetu Jagiellońskiego" oprócz omówienia zasobu archiwum pochyliła się również nad problemem przejmowania dokumentacji przez archiwa uniwersyteckie i funkcją urzędową, którą pełnią. Archiwa te kładą przede wszystkim nacisk na przejmowanie akt studenckich i registratury uniwersyteckiej, w dalszej kolejności zajmując się materiałami pochodzącymi z poszczególnych zakładów i katedr naukowych. Wynika to przede wszystkim z funkcji archiwum, pewien wpływ ma również niechęć jednostek badawczych do przekazywania swojej dokumentacji, która spowodowana jest ciągłym wykorzystywaniem zgromadzonych akt $\mathrm{w}$ dalszych badaniach.

Ewa Dziurzyńska z Archiwum Nauki PAN i PAU przedstawiła „Różnorodność źródeł do historii nauki na wybranych przykładach Archiwum Nauki Polskiej Akademii Nauk i Polskiej Akademii Umiejętności”. W artykule zebrano najciekawsze przykłady z zasobu archiwum, które miały zilustrować ową różnorodność. Autorka podaje, że jego zbiory w 2010 roku 
stanowiło 56 zespołów pochodzenia kancelaryjnego i 219 spuścizn uczonych. Publikacja opatrzona została wieloma ilustracjami.

Komunikaty, w których przedstawiono wybrane instytucje archiwalne, ich historię oraz zasób, zostały zaprezentowane przez Janinę Potocką-Schwartz oraz Lidię Serbin-Zubę. Pierwsza autorka omówiła Archiwum Matematyków Polskich przy Oddziale Gdańskim Instytutu Medycznego PAN w Sopocie, druga przybliżyła Archiwum Historyczne Elektroenergetyki Polskiej, które znajduje się w Toruniu.

Na końcu publikacji umieszczono najważniejsze głosy w dyskusji, która odbyła się po sesji plenarnej. Wzięli w niej udział m.in. Piotr Hübner z Uniwersytetu Mikołaja Kopernika, Jerzy Pawłowski z Instytutu Systematyki i Ewolucji Zwierząt PAN, Julian Dybiec z Uniwersytetu Jagiellońskiego, Halina Robótka z Uniwersytetu Mikołaja Kopernika. Dyskutanci ustosunkowali się do przedstawionych poglądów oraz wyrazili swoje opinie na temat materiałów gromadzonych przez archiwa naukowe, wyrazili również swoje oczekiwania względem tych instytucji.

Przedstawiona publikacja zasługuje na szczególną uwagę, ponieważ porusza problemy, z którymi w chwili obecnej borykają się badacze historii nauki i archiwiści opracowujący spuścizny po uczonych. Stanowi ona dowód na to, że historia nauki jest nadal żywa i cieszy się rosnącą popularnością wśród badaczy. 